\title{
Caro Leitor
}

Esta edição comemora 7 anos de publicação da revista dObra[s]. Nesse período estivemos sempre muito atentas tanto ao teor das pesquisas desenvolvidas no Brasil quanto às possiveis interlocuções com os estudos produzidos fora do país. Procuramos acompanhar a legislação e as normas para que tivéssemos uma revista científica bem avaliada, além de graficamente diferenciada, para dar visibilidade aos pesquisadores de Moda, "mas não só", especialmente do todo o Brasil.

A pesquisa no país, na Moda e áreas correlatas, cresce e a cada dia ampliam-se, sobremaneira, as oportunidades de apresentação e discussão de trabalhos acadêmicos, em vários eventos, em diferentes estados brasileiros e, igualmente, no exterior, em congressos e seminários nos quais se reconhece a língua portuguesa como língua oficial, como é o caso, por exemplo, do Congresso Internacional de Moda e Design - CIMODE -, que ocorrerá em novembro, no Politecnico di Milano, na Itália, em sua segunda edição - a primeira aconteceu em Guimarães (Portugal), em 2012 -, e onde apresentaremos esta revista.

Importante lembrar que a primeira edição de dObra[s] foi lançada em 2007, durante o 3 ํㅡ Colóquio de Moda, em Belo Horizonte (MG), e, desde então, a cada ano, uma edição da revista é divulgada durante este que é, na atualidade, o maior evento da área de Moda em âmbito nacional - neste ano, foram mais de mil inscritos e cerca de quatrocentos trabalhos aprovados por um Conselho Científico formado por 83 pesquisadores doutores e 40 mestres. Em 2014, o Colóquio de Moda comemorou 10 anos. Então, motivos para nos alegrarmos não nos faltam!!!

A aproximação com a Associação Brasileira de Estudos e Pesquisas em Moda (Abepem) que dirige o Colóquio de Moda, entre outros importantes eventos científi$\cos$, nos fez entender que dObra[s] poderia alçar novos voos e ganhar mais força para a representação do universo da moda, ampliando as possibilidades de crescimento e visibilidade das pesquisas (e pesquisadores), visando a uma melhor pontuação nos órgãos de avaliação e de publicação na área.

Assim, comunicamos que, a partir do próximo ano, dObra[s] será a revista científica em Moda e Design da Abepem. Para isso, contará com uma diretoria específica para cuidar das edições da revista e também apoiará e desenvolverá publicações sob sua chancela. Mudança é sinal de crescimento, de busca e adequação ao amadurecimento que a própria área vem demonstrando.

Nesta edição contamos com quatro participações especiais entre nossos colunistas. Daniela Auler que vem fazendo um belíssimo trabalho de inclusão social com a Secretaria de Estado dos Direitos da Pessoa com Deficiência de São Paulo e mostrando como a moda faz, de fato, a diferença na vida das pessoas. Jô Souza, entre outras tantas coisas que produz, é apaixonada pela linguagem cinematográfica e faz exercícios de leitura especializadíssima para o entendimento da moda. A designer Anna Vörös traz um olhar muito especial voltado às questões sociais e suas manifestações culturais. 0 jornalista Eduardo Motta sempre nos encanta com sua clareza nas relações que estabelece entre a moda e outras áreas de conhecimento.

Igualmente prazerosa é a participação de nossos colunistas fixos, muitos nos acompanham desde a primeira edição - Ana Claudia de Oliveira, Carol Garcia, Cristiane Mesquita, Fausto Viana, João Braga, Maria Lucia Bueno, Rosane Preciosa e Sylvia Demetresco.

Os artigos internacionais pontuam duas importantes instituições que submetem textos à revista com regularidade - a Universidade de Roma (Itália) e a Universidade do Minho (Portugal). Pierluigi Cervelli trata do design anônimo e aponta como em tais objetos encontram-se explícitos seus modos de uso. Um estudo que entendemos ainda não tratado e discutido por aqui. Maria Gabriela Gama discorre sobre o sex appeal das marcas, ou seja, como a marca constrói um universo de valores que produz mitologias contemporâneas.

Renata Pitombo Cidreira nos dá a oportunidade de refletir a respeito de uma questão muito comentada e pouco organizada teoricamente: Qual é o espaço da crítica de moda no Brasil? É a pergunta que nos faz a autora. Questão fundamental para o desenvolvimento do espírito e narrativas críticos. 


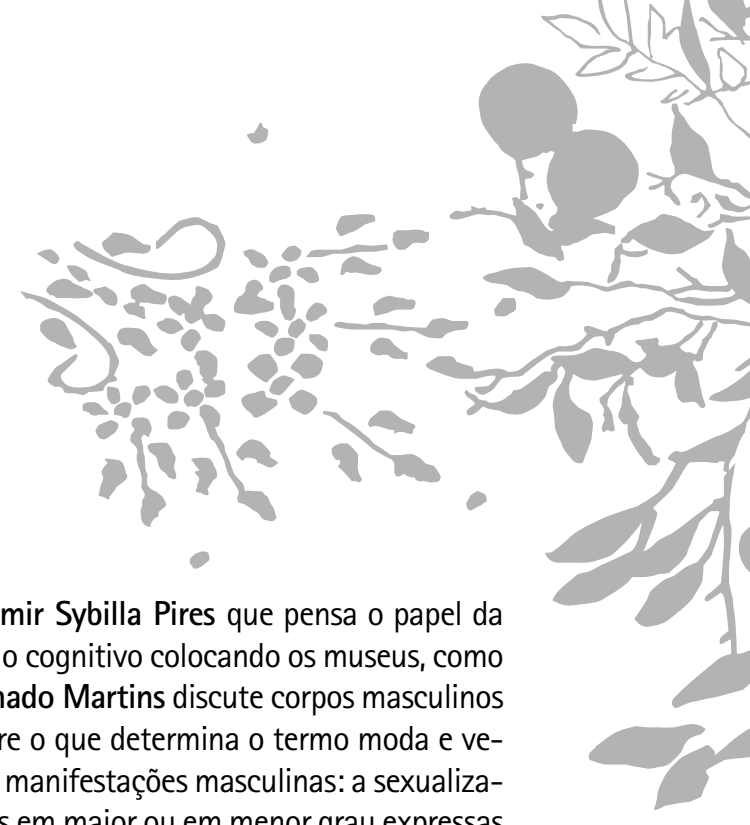
ção, a erotização e a sensualidade tematizadas em maior ou em menor grau expressas em campanhas publicitárias.

Patrícia de Mello Souza faz um importante estudo sobre a relação da moda e da arquitetura, na composição de espaços e de princípios que determinam modos de vestir e revestir pensados por meio de projetos estruturais da área do design. Raquel Carvalho Maia analisa a estamparia da moda praia brasileira e uma possível relação com o "mito fundador".

A filosofia e os estudos contemporâneos sobre a moda são o alvo do artigo de Suzie Nascimento que nos traz o pensamento nietzschiano e propõe tratar da indumentária sob o viés do impulso criativo. Izabel Haddad Marques Massara conta uma história real com nuances dos contos fantásticos do século XIX que tem a seda como protagonista, ícone de leveza e liberdade e insígnia de feminilidade.

Mônica Moura começa agradecendo a possibilidade de entrevistar Dijon De Moraes e este agradecimento é também nosso! Profissional superatuante no campo do design e que ajuda a construir o design brasileiro. A entrevista é uma aula cheia de incursões e reflexões sobre seus livros, memória e mudanças no design brasileiro, mercado, criação e muito mais.

Nizia Villaça foi quem sugeriu e acompanhou a entrevista internacional com Georges Bertin que fala dos estudos sobre o imaginário ou, mais especificamente, sobre a socioantropologia do imaginário que abre perspectivas interessantíssimas para o estudo da moda, esporte, religiões, saúde, redes digitais etc.

A linda capa desta edição realizada por Marcelo Max, designer que nos acompanha desde o início de dObra[s], tem por base os bordados poéticos de Clarice Borian, artesã, artista, ex-empresária da área do vestuário e, como ela mesma diz, "palpiteira e consultora de ideias e projetos que buscam uma identidade autoral".

Para finalizar, gostariamos aqui de prestar nossa homenagem à professora Doroteia Baduy Pires que sempre esteve muito presente como amiga, autora e parecerista de dObra[s]. Seu modo elegante e competente de tratar a articulação entre o Design e a Moda nos deixa um importante legado. Agradecemos sua amizade e parceria e estamos certas de que sentiremos muito sua falta e continuaremos trabalhando com o entusiasmo que lhe era tão característico para que nossos projetos se efetivem e tenhamos o Design de Moda como uma área exemplar de pesquisas em nível nacional e internacional também.

É lembrando o charme da inesquecivel e deliciosa pronúncia da palavra "design", que tanto nos aproximou e divertiu que esta edição da revista é dedicada a você, querida Doroteia Baduy Pires. Nosso intuito é deixar um registro de gratidão por tudo que fez, pelo que tanto trabalhou em prol do entendimento e estruturação no campo da Moda e do Design em nosso país. Reconhecimento e saudade são sentimentos que se eternizam.

A você, nosso leitor, agradecemos sempre pela possibilidade de troca, por utilizar a revista em suas fontes de pesquisa, por acompanhar e, muitas vezes, discutir em seus trabalhos os artigos apresentados em dObra[s]. É assim que se constrói um campo do saber, nos encontros, nos debates, e também nas publicações que se tornam referências e que geram novas possibilidades de abordagem e de "olhares diversos".

Excelente leitura e aguardem nossas novidades no próximo ano!

Abraço carinhoso, 